MACHINE BUILDING

МАШИНОБУДУВАННЯ

UDC 519.2
A. Fürstenzelle ${ }^{1}$,
F. Tóth ${ }^{1}, \mathrm{PhD}$,
M. Kadná ${ }^{1}$, PhD, Assoc. Prof.,
J. Rusnák ${ }^{1}$, DSc, Prof.,
M. Bošanský ${ }^{2}$, DSc, Prof.,

M. Mráz

${ }^{1}$ Slovak University of Agriculture in Nitra, 2 Tr. A. Hlinku, Nitra, Slovakia, 94976; xfurstenzell@is.uniag.sk

${ }^{2}$ Slovak University of Technology in Bratislava, 17 Námestie Slobody, Bratislava, Slovakia, 81231; e-mail: miroslav.bosansky@stuba.sk

\title{
COMPARISON OF TRIBOLOGICAL PROPERTIES OF HCR GEARS COATED BY PVD COATING TiAIN+DLC IN BIO-FRIENDLY AND CONVENTIONAL LUBRICATION ENVIRONMENTS
}

\begin{abstract}
А. Фурстензеллер, Ф. Тот, М. Каднар, Ю. Руснак, М. Бошански, М. Мраз. Порівняння трибологічних властивостей HCR шестерен 3 високим контактним коефіціснтом PVD покриттям TiAlN+DLC в біологічних i звичайних мастильних середовищах. У представленому науковому експерименті йдеться про застосування покриття PVD (Physical Vapor Deposition) TiAlN+DLC у двох різних середовищах змащування, а також порівнюється термін експлуатації покриття у згаданих мастильних матеріалах. PVD-покриття TiAIN+DLC було обрано згідно 3 попередніми експериментами, які проводились в лабораторних роботах Словацького університету сільського господарства у Нітрі. Покриття наносилося на шестерні HCR (High Contact Ratio) iз властивостями, описаними у главі матеріали та методи. Шестерні HCR були вибрані відповідно до попередніх досліджень, проведених на цьому типі передач. Шестірні HCR виготовлялися з матеріалу $14220\left(16 \mathrm{MnCr}_{5}\right)$.В якості мастильних середовищ було обрано екологічну мастило OMW Biogear S150 та звичайну мастильну речовину MADIT PP 90Н. Ці два мастила були відібрані відповідно до застосування в попередніх дослідженнях, проведених на робочому місці. Експериментальні випробування проводилися на випробувальній установці Niemann M01 FZG (back-to-back). Ця випробувальна установка була використана для всебічного вимірювання. В ході експерименту ми дотримувались стандарта STN 656280 для тестів на FZG, з якого ми отримали значення навантаження для різних рівнів навантаження. Після кожного рівня навантаження вимірювались значення максимальної висоти профілю Rz за допомогою портативного тестера шорсткості поверхні Mitutoyo SJ-201 для наконечника та еталонного діаметру зубчастого колеса і шестерні. Результати експериментальних випробувань були статистично оброблені і на їх основі були встановлені співвідношення між максимальною висотою оцінюваного профілю та рівнем навантаження для обох використаних мастильних матеріалів як залежності зміни максимальної висоти оцінюваного профілю Rz від рівня навантаження. Проведені експерименти показали, що застосування PVD покриття TiAIN+DLC можливе в обох використовуваних середовищах.

Ключові слова: біологічне масло, шестерні HCR, PVD покриття TiAlN+DLC, тест FZG

A. Fürstenzeller, F. Tóth, M. Kadnár, J. Rusnák, M. Bošanský, M. Mráz. Comparison of tribological properties of HCR gears coated by PVD coating TiAIN+DLC in bio-frendly and conventional lubrication environments. The submitted scientific experiment deals with the application of PVD (Physical Vapour Deposition) coating TiAlN+DLC in two different lubrication environments, also the article deals with the comparison of a lifetime of coating in mentioned lubricants. The PVD coating TiAlN+DLC was selected according to previous experiments carried out in the same field of laboratory works at Slovak University of Agriculture in Nitra. The coating was deposited on HCR (High Contact Ratio) gears with properties explained in chapter Materials and methods. HCR gears were selected according to the previous research performed on that type of gears. HCR gears were made from material $14220\left(16 \mathrm{MnCr}_{5}\right)$. As lubrication environments were chosen ecological lubricant OMW Biogear S150 and conventional lubricant MADIT PP 90H. These two lubricants were selected according to the application in the previous research carried out in the workplace.Experimental tests were performed on the Niemann M01 FZG testing rig (back-to-back). That testing rig was used for the comprehensive measurement of the scuffing tests. In the experiment, we followed standard STN 65 6280, for FZG scuffing tests, from which we gained the load values for different load levels. After each load level were measured values of the maximum height of the measured profile Rz, by portable surface roughness tester Mitutoyo SJ-201, for the tip and the reference diameters on gear and pinion. Results of experimental tests were statistically processed and on a basis on them were established relations between the maximum height of the assessed profile and load level for both used lubricants as the dependence of change maximum height of the assessed profile Rz on the load level. Performed experiments showed that application of PVD coating TiAlN+DLC is possible in both used environments.
\end{abstract}

Keywords: biological oil, HCR gears, PVD coating TiAlN+DLC, FZG test

DOI: 10.15276/opu.2.58.2019.01

(c) 2019 The Authors. This is an open access article under the CC BY license (http://creativecommons.org/licenses/by/4.0/). 


\section{Introduction}

Gears and power transmissions are among the oldest mechanisms used in engineering. They were used whenever a man wanted to transfer mechanical energy to a working machine. Gears have undergone a long way of development to today's modern form of technology [1, 2].

Standard involute gears use a Normal Contact Ratio (NCR), i.e. the contact ratio $\varepsilon_{\alpha}$. is in the range of 1 to 2. One pair of teeth in contact alternate with two pairs of teeth in contact. To ensure smooth operation, the minimum contact ratio $\varepsilon_{\alpha}=1.2$ is preferred. Gears should generally not be designed to have less than 1.2 contact ratio, because mounting inaccuracies may further decrease $\varepsilon_{\alpha}$, thus increasing the possibility of impact between the teeth as well as an increase in the noise level. Contact ratios of standard involute gears are generally in range of 1.4 to 1.6. For example, contact ratio $\varepsilon_{\alpha}=1.6$ means that two pairs of teeth are in contact $60 \%$ of the time and one pair of teeth is in contact $40 \%$ of the time $[3,4,5]$.

High Contact Ratio (HCR) gears are non- standard gears with a modified form of a basic involute profile [6]. Changes relate to addendum height, it is not equal 1 like for standard involute gears. Addendum height $h_{a}{ }^{*}$ is increased and bigger than one, $h_{a}{ }^{*}>1$. The results are gears with contact ratio $\varepsilon_{\alpha} \geq 2$. The teeth with this profile can reach contact ratio up to $4[7,8]$.

We used the PVD coating method due to a more appropriate temperature course during coating and lower procurement cost. We could not use another method of coating with higher deposition temperatures because the gears were surface hardened and the deposition temperature would be higher than the quench temperature $[9,10]$. After considering these factors and possibilities in cooperation with LISS, we decided to use PVD coating. The production of coating was carried out in laboratories of LISS. The selected coating was deposited using the ARC PVD method on the device $\pi$ 411PLUS. Parameters of coating used are described in chapter Materials and Methods.

The aim of the presented study is to evaluate possibility of application PVD coating TiAlN+DLC deposited on HCR gears in environments lubricated by conventional and ecological lubricants. The article follows previous experiments performed on HCR gearing in the Center of Innovation at Faculty of Mechanical Engineering, Slovak University of Technology in Bratislava.

\section{Material and Methods}

Experimental tests were performed in the Center of Innovation laboratories at Faculty of Mechanical Engineering, Slovak University of Technology in Bratislava. In experiment, we followed STN 656280 standard for FZG scuffing tests, from which we gained the load values for different load levels [11]. To perform an experiment, we used a FZG test rig (back-to-back) with closed performance flow, portable surface roughness tester Mitutoyo SJ-201 and ultrasonic cleaner Ecosom U7-STH [12, 13].

The Niemann M01 device was developed in the laboratories of Slovak University of Technology in Bratislava for the comprehensive measurement of the scuffing tests. The Niemann M01 gear test rig is a back-to-back rig (Fig. 1).

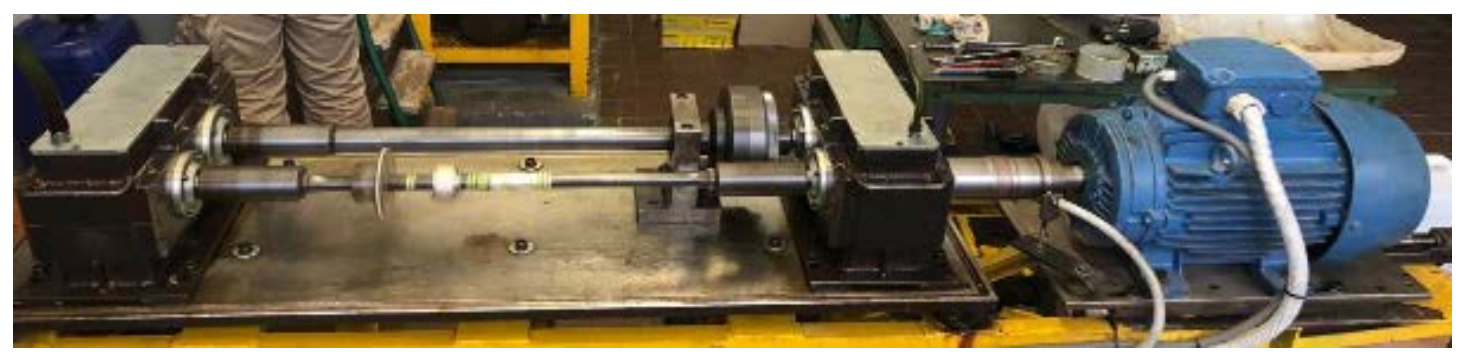

Fig. 1. Measuring device Tribotestor M'06 and a detailed view of the measuring head and test samples

The Niemann M01 is mounted on a concrete base equipped with vibration-damping feet. The device as a whole is consisted of two main parts, namely test chamber and slave chamber, where test gears and slave gears are located. These two chambers are connected to each other by two shafts. One shaft serves only as a connection between the chambers. The second shaft is composed of two parts 
which are connected by a load clutch. By load clutch both parts of shaft can be rotated against each other and in that position they can be fixed. The left part of load clutch is fixed to the base with the lock-pin via the clutch and its support. The right part of the load clutch is rotated by loading lever and weights to create a static loading torque in the system. When the load has been applied, the two halves of the clutch are fixed against movement with the bolts. Then, the lock-pin is safely removed. The twist size varies according to the load required, but only by step change and not during the run of the device $[14,15]$.

The device Niemann M01 itself is complemented by a number of devices for tracking measured data during machine operation. These devices serve as a feedback to the data set before the measurement.

The device is driven by a three-phase electric motor with a frequency converter, which makes it possible to set the output speed of the electric motor as required (Fig. 2.).

The rotation of load clutch itself and load adjustment in system are performed by using lever. The weight is suspended on the lever to obtain the desired torque on the pinion shaft (Fig. 3.)

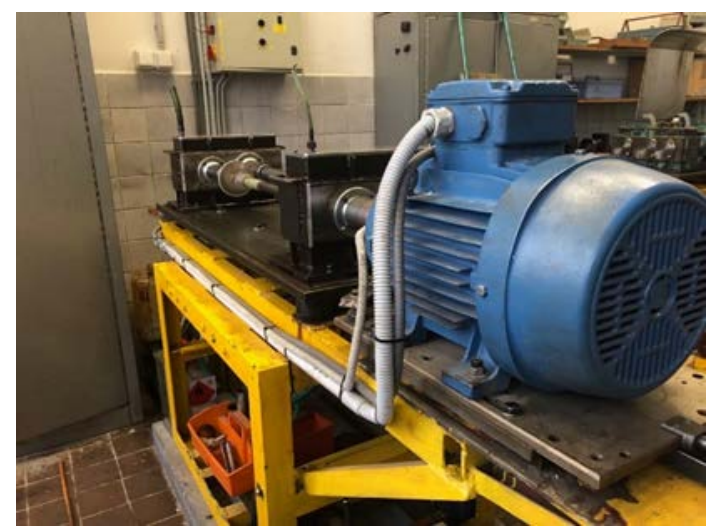

Fig. 2. Three-phase electric motor of Niemann M01

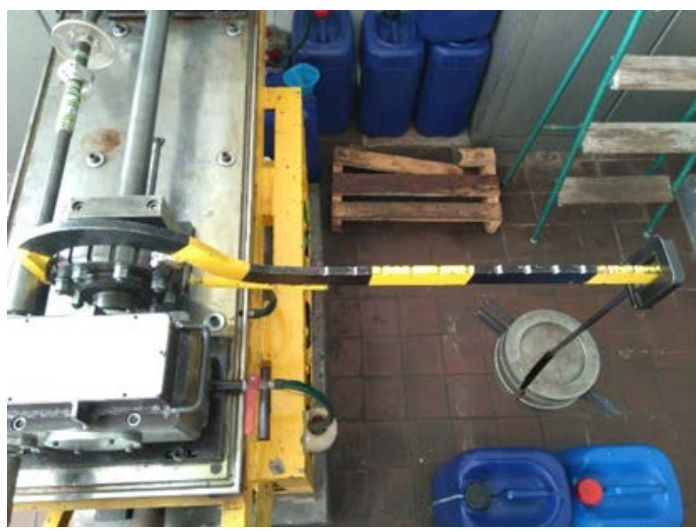

Fig. 3. Three-phase electric motor of Niemann M01

Used lubricants for experimental tests were OMV BioGear S 150 and MADIT PP90H. The reason for using biological and conventional lubricants was to test the durability and resistance of coating in selected lubricants under extreme conditions. The reasons for using specific types of lubricant, OMV Biogear S150 and MADIT PP 90H, were previous usage in experiments at the Center of Innovation and thus that possibility of comparison with previous research. OMV Biogear S 150 is a fully synthetic, biodegradable, industrial gear oil based on synthetic environment-friendly esters. Its basic specifications shows Table 1 . It is designed for mechanically and thermally heavy load transmissions of various constructions, for bearing lubrication in agriculture, forestry, construction industry, shipping and protected natural areas.

MADIT PP $90 \mathrm{H}$ is a year-round transmission oil designed to lubricate extremely heavy-duty transmissions and final-drive assemblies of modern cars and other mobile technology. Its basic specifications shows Table 2. It is suitable for gearboxes working in extremely difficult operating conditions. It is designed for hypoid transmissions. It is preferred to use it at elevated temperatures when reliable function is guaranteed.

Table 1

Technical data of OMV Biohyd S 150

\begin{tabular}{c|c}
\hline Property & Value \\
\hline Viscosity at $40{ }^{\circ} \mathrm{C}$ & $150.00 \mathrm{~mm}^{2} / \mathrm{s}$ \\
\hline Viscosity at $100^{\circ} \mathrm{C}$ & $24.45 \mathrm{~mm}^{2} / \mathrm{s}$ \\
\hline Ignition point & $224^{\circ} \mathrm{C}$ \\
\hline Pour point & $-27^{\circ} \mathrm{C}$ \\
\hline Density at $15^{\circ} \mathrm{C}$ & $945 \mathrm{~kg} / \mathrm{m}^{3}$ \\
\hline Viscosity index & 167 \\
\hline
\end{tabular}

Table 2

Technical data of MADIT PP $90 \mathrm{H}$

\begin{tabular}{l|c}
\hline Property & Value \\
\hline Viscosity at $40{ }^{\circ} \mathrm{C}$ & $140.00 \mathrm{~mm}^{2} / \mathrm{s}$ \\
\hline Viscosity at $100^{\circ} \mathrm{C}$ & $15.00 \mathrm{~mm}^{2} / \mathrm{s}$ \\
\hline Ignition point & $200^{\circ} \mathrm{C}$ \\
\hline Pour point & $-27^{\circ} \mathrm{C}$ \\
\hline Density at $15^{\circ} \mathrm{C}$ & $905 \mathrm{~kg} / \mathrm{m}^{3}$ \\
\hline Viscosity index & 95 \\
\hline
\end{tabular}


Portable surface roughness tester Mitutoyo SJ-201 with a retrofitted measuring apparatus was used for measuring of roughness before loading and after each load stages. We installed the device on the apparatus and then was measured maximum height of the assessed profile Rz on tip and reference diameter on both pinion and gear. Before every measurement were pinion and gear degreased, washed in technical gasoline, cleaned from oil residues in ultrasonic cleaner and dried with flow of air. Table 3 shows technical parameters of Mitutoyo SJ-201 and Fig. 4. shows the process of measuring of roughness.

Table 3

Technical parameters of Mitutoyo SJ-201

\begin{tabular}{c|c}
\hline Property & Value \\
\hline Measuring range & $0.015 \ldots . .350 \mu \mathrm{m}$ \\
\hline Measuring speed & $0.25 \ldots 0.5 \mathrm{~mm} / \mathrm{s}$ \\
\hline Stylus tip material & Diamond \\
\hline Stylus tip radius & $1 \ldots 5 \mu \mathrm{m}$ \\
\hline Operating temperature & $5 \ldots . .40^{\circ} \mathrm{C}$ \\
\hline
\end{tabular}

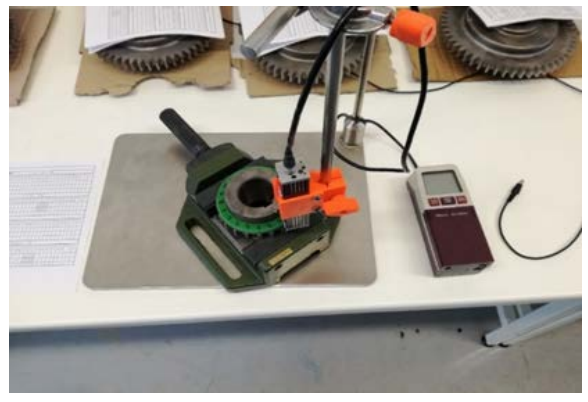

Fig. 4. Process of measuring of roughness by Mitutoyo SJ-201

The test gears were made of $16 \mathrm{MnCr} 5$ steel. They were carburized, case hardened and tempered before coating. The basic parameters like number of teeth of pinion and gear are shown in Table 4 .

For the experimental tests, we selected PVD coating TiAlN+DLC. Table 5 shows properties of PVD coating. The selected coating is manufactured at a thickness of from 1 to $7 \mu \mathrm{m}$. In the presented experiment, the coating thickness was $7 \mu \mathrm{m}$ according to the used standard.

Experimental tests of coating were performed in 2 phases. In the first phase, experiments were carried out with OMV Biogear S150 ecological lubricant and in second phase was carried out experiments with conventional lubricant MADIT PP 90H. After completion of both phases, we continued to test other coating.

Table 4

Preparation of the test:

To avoid errors and inaccuracies, several steps Main parameters of test HCR gears

\begin{tabular}{c|c}
\hline Property & Value \\
\hline Transmission ratio & $i=2.43$ \\
\hline Center distance & $a=144 \mathrm{~mm}$ \\
\hline Module & $m=4 \mathrm{~mm}$ \\
\hline $\begin{array}{c}\text { Number of teeth } \\
\text { - pinion } \\
\text { - gear }\end{array}$ & $z_{1}=21$ \\
$z_{2}=51$ \\
\hline Facewidth & $b=15 \mathrm{~mm}$ \\
\hline Reference cylinder helix & $\beta=0^{\circ}$ \\
angle & $\alpha=20^{\circ}$ \\
\hline Reference pressure angle & $h_{a}{ }^{*}=1.3$ \\
\hline Addendum & $h_{f}{ }^{*}=1.7$ \\
\hline Dedendum & \\
\hline Profile shift correction & $x_{1}=0.4$ \\
- pinion & $x_{2}=-0.4$ \\
\hline - gear & \\
\hline Tip diameter & $d_{a 1}=97.6 \mathrm{~mm}$ \\
- pinion & $d_{a 2}=2 \mathrm{~mm}$ \\
\hline gear & $\varepsilon_{\alpha}=2.003$ \\
\hline Transverse contact ratio
\end{tabular}
had to be taken before each test in order to prepare device and test gears:

- cleaning the chambers twice with a suitable solvent, before starting a new series of experiments with a different lubricant,

- cleaning the pinion and the gear in a solvent,

- weighing the pinion and the gear on the scale with accuracy of at least $1 \mathrm{mg}$.

The conditions of the experiment were determined by standard STN 65 6280:

Table 5

Properties of TiAlN + DLC coating

\begin{tabular}{c|c}
\hline Property & Value \\
\hline Color & Violet-black \\
\hline Nanohardness up to & $36 \mathrm{GPa}$ \\
\hline Thickness & $1 \ldots 7 \mu \mathrm{m}$ \\
\hline Friction coeff. & 0.60 \\
\hline Max. usage temp. & $700^{\circ} \mathrm{C}$ \\
\hline Deposition temperature & $480^{\circ} \mathrm{C}$ \\
\hline
\end{tabular}


- the required circumferential velocity on the pinion $-v=6.4 \mathrm{~m} / \mathrm{s}$, which in our case corresponded to the pinion revolutions of $1450 \mathrm{rpm}$,

- duration for each load stage - 20.6 min. This shows that the test pinion has performed 30.000 cycles [7].

Expected procedure for the experiment:

- insertion of the testing gears into test chamber, pour oil into the chamber and assembling the measuring device,

- load the test gears with torque according standard,

- launch the device for $20.6 \mathrm{~min}$,

- draining used oil,

- demounting of the test chamber and removal of the test gear,

- degreasing gears, washing the gears in technical gasoline and cleaning from oil residues in the ultrasonic cleaner, drying gears with the flow of dry air,

- weighing gears and measuring of roughness.

\section{Results and Discussion}

In the scientific paper, we performed experimental tests on HCR gears, coated with TiAlN+DLC coating. In experiments, we followed STN 656280 standard for FZG scuffing tests and we used Nieman M01 (back-to-back) testing rig. As lubricants, we chose conventional lubricant MADIT PP 90H and ecological lubricant OMW Biogear S150. The results obtained from experimental tests were statisticallyprocessed and assessed. Test results were graphically evaluated as course of the maximum height of the assessed profile Rz depending on the load level. The increasing load level was followed by a gradual increase of the $\mathrm{Rz}$ values which were caused by abrasion of the coating layers. When the value of the Rz reaches a limit $7 \mu \mathrm{m}$, this load level is marked as a border level of load.

The Tables presented in the chapter Results and discussion contain statistical data from the measurements. For the measurement of each parameter was selected interval of 10 values $(n=10)$. The Tables contain values of the arithmetic mean $\overline{\mathrm{Rz}}$ the standard deviation Sand the standard error of the mean $S_{\overline{\mathrm{Rz}}}$.

Table 6 represents values of the maximum height of assessed profile $\mathrm{Rz}$ for pinion in lubricant Biogear S150.

Table 7 represents values of the maximum height of assessed profile Rz for gear in lubricant Biogear S150.

Table 8 represents values of the maximum height of assessed profile $\mathrm{Rz}$ for pinion in lubricant MADIT PP 90H.

Table 9 represents values of the maximum height of assessed profile $\mathrm{Rz}$ for gear in lubricant MADIT PP 90H.

From Tables 6, 7, 8, 9 is evident that values did not reached value $7 \mu \mathrm{m}$.

The graphs shown on figures in chapter Results and discussion show a change of the maximum height of the assessed profile Rz depending on the load level for the pinion or the gear. There are 3 lines in graphs. The limit value of the maximum height of the assessed profile $\mathrm{Rz}(7 \mu \mathrm{m})$ is represented by red colour. Blue colour represents tip diameter and orange colour represents the reference diameter of the maximum height of the assessed profile Rz. It is clear from the graphs descriptions, which parameters are described.

Fig. 5 represents dependence of change maximum height of the assessed profile $\mathrm{Rz}$ on load level for pinion in OMW Biogear S150.

Fig. 6 represents dependence of change maximum height of the assessed profile $\mathrm{Rz}$ on load level for gear in OMW Biogear S150.

Fig. 7 represents dependence of change maximum height of the assessed profile Rz on load level for pinion in MADIT PP $90 \mathrm{H}$.

Fig. 8 represents dependence of change maximum height of the assessed profile $\mathrm{Rz}$ on load level for gear in OMW MADIT PP $90 \mathrm{H}$. 
Values of the maximum height of the assessed profile Rz (pinion, TiAlN+DLC, Biogear S150)

\begin{tabular}{c|c|c|c|c|c|c|c|c}
\hline \multirow{2}{*}{$\begin{array}{c}\text { Load } \\
\text { level }\end{array}$} & \multicolumn{4}{|c|}{ Tip diameter } & \multicolumn{4}{c}{ Reference diameter } \\
\cline { 2 - 8 } & $n$ & $\overline{\mathrm{Rz}}(\mu \mathrm{m})$ & $S(\mu \mathrm{m})$ & $S_{\overline{\mathrm{Rz}}(\mu \mathrm{m})}$ & $n$ & $\overline{\mathrm{Rz}}(\mu \mathrm{m})$ & $S(\mu \mathrm{m})$ & $S_{\overline{\mathrm{Rz}}}(\mu \mathrm{m})$ \\
\hline 3 & 10 & 6.920 & 0.137 & 0.043 & 10 & 6.410 & 0.113 & 0.036 \\
\hline 4 & 10 & 5.760 & 0.127 & 0.040 & 10 & 4.710 & 0.098 & 0.031 \\
\hline 5 & 10 & 6.210 & 0.134 & 0.042 & 10 & 5.070 & 0.144 & 0.036 \\
\hline 6 & 10 & 4.910 & 0.176 & 0.056 & 10 & 5.350 & 0.130 & 0.033 \\
\hline 7 & 10 & 5.030 & 0.160 & 0.034 & 10 & 4.360 & 0.121 & 0.038 \\
\hline 7.5 & 10 & 4.830 & 0.139 & 0.044 & 10 & 5.890 & 0.114 & 0.036 \\
\hline 8 & 10 & 6.340 & 0.128 & 0.041 & 10 & 3.970 & 0.134 & 0.042 \\
\hline 9 & 10 & 4.840 & 0.117 & 0.037 & 10 & 2.710 & 0.123 & 0.039 \\
\hline 10 & 10 & 5.790 & 0.145 & 0.046 & 10 & 2.870 & 0.136 & 0.043 \\
\hline 11 & 10 & 5.780 & 0.145 & 0.046 & 10 & 3.940 & 0.104 & 0.033 \\
\hline 12 & 10 & 5.080 & 0.128 & 0.040 & 10 & 2.240 & 0.096 & 0.030 \\
\hline
\end{tabular}

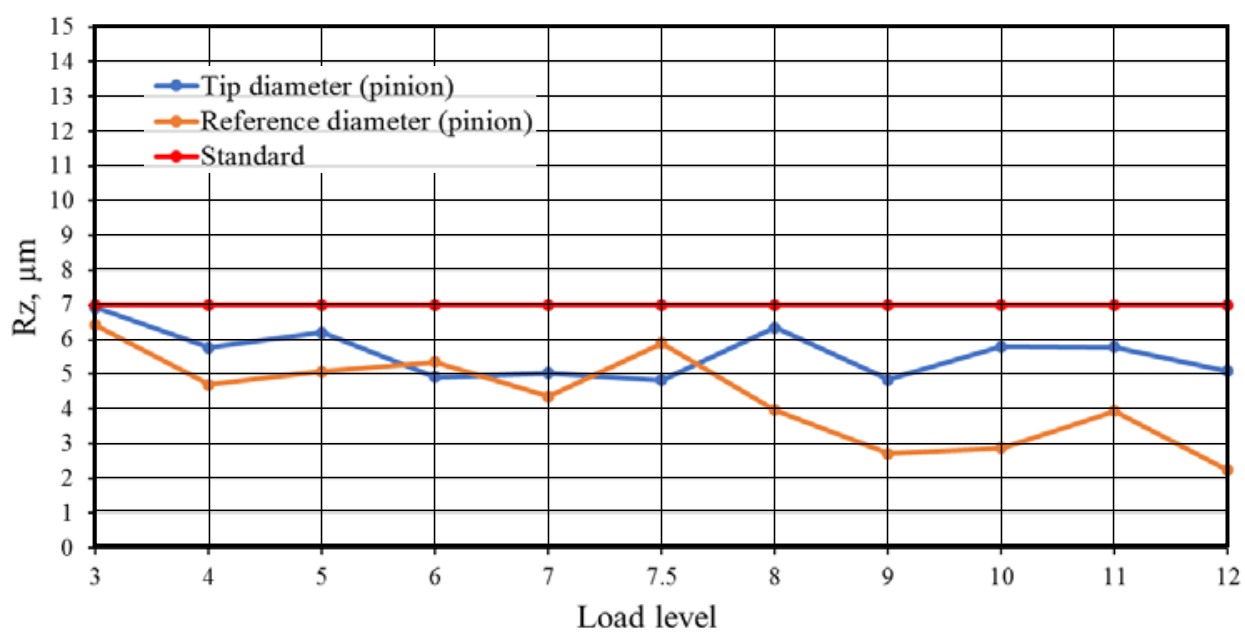

Fig. 5. Dependence of change maximum height of the assessed profile $R z$ on load level for TiAlN+DLC in OMW Biogear S150 (pinion)

Values of the maximum height of the assessed profile $\mathrm{Rz}$ (gear, TiAIN+DLC, Biogear S150)

\begin{tabular}{c|c|c|c|c|c|c|c|c}
\hline \multirow{2}{*}{$\begin{array}{c}\text { Load } \\
\text { level }\end{array}$} & \multicolumn{4}{|c|}{ Tip diameter } & \multicolumn{4}{c}{ Reference diameter } \\
\cline { 2 - 8 } & $n$ & $\overline{\mathrm{Rz}}(\mu \mathrm{m})$ & $S(\mu \mathrm{m})$ & $S_{\overline{\mathrm{Rz}}}(\mu \mathrm{m})$ & $n$ & $\overline{\mathrm{Rz}}(\mu \mathrm{m})$ & $S(\mu \mathrm{m})$ & $S_{\overline{\mathrm{Rz}}}(\mu \mathrm{m})$ \\
\hline 3 & 10 & 5.510 & 0.089 & 0.028 & 10 & 6.730 & 0.094 & 0.030 \\
\hline 4 & 10 & 6.250 & 0.139 & 0.044 & 10 & 5.750 & 0.086 & 0.027 \\
\hline 5 & 10 & 5.740 & 0.116 & 0.037 & 10 & 4.890 & 0.084 & 0.026 \\
\hline 6 & 10 & 5.410 & 0.106 & 0.033 & 10 & 4.870 & 0.085 & 0.027 \\
\hline 7 & 10 & 5.210 & 0.088 & 0.028 & 10 & 4.870 & 0.067 & 0.021 \\
\hline 7.5 & 10 & 5.440 & 0.102 & 0.032 & 10 & 4.230 & 0.076 & 0.024 \\
\hline 8 & 10 & 6.060 & 0.122 & 0.039 & 10 & 4.340 & 0.095 & 0.030 \\
\hline 9 & 10 & 5.970 & 0.096 & 0.030 & 10 & 5.320 & 0.0118 & 0.037 \\
\hline 10 & 10 & 4.460 & 0.106 & 0.034 & 10 & 5.240 & 0.070 & 0.022 \\
\hline 11 & 10 & 5.510 & 0.099 & 0.031 & 10 & 4.790 & 0.090 & 0.028 \\
\hline 12 & 10 & 5.450 & 0.098 & 0.032 & 10 & 4.140 & 0.079 & 0.025 \\
\hline
\end{tabular}




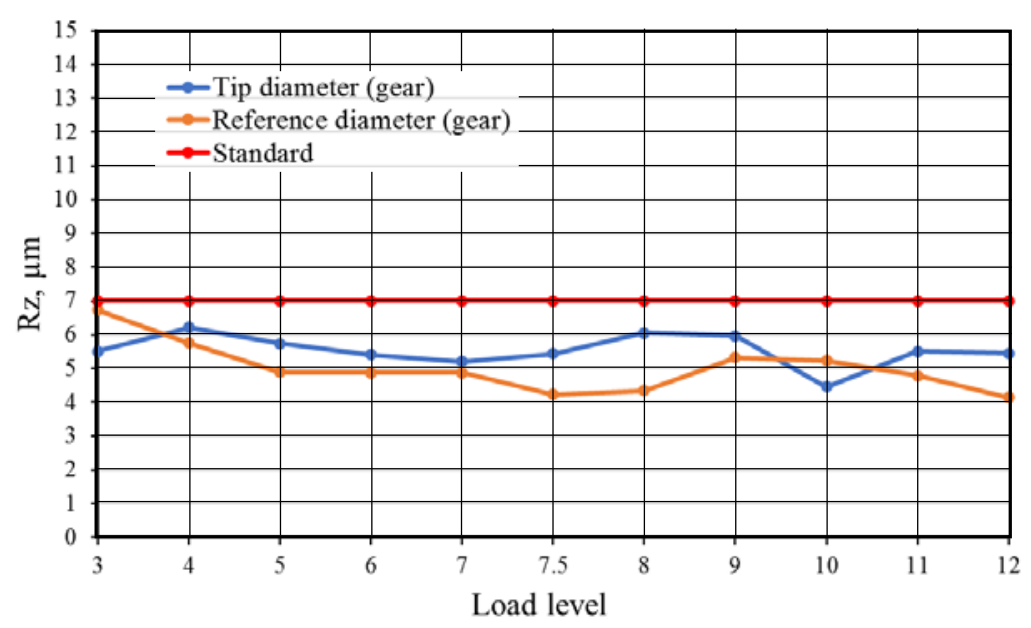

Fig. 6. Dependence of change maximum height of the assessed profile $\mathrm{Rz}$ on load level for TiAIN+DLC in OMW Biogear S150 (gear)

Table 8

Values of the maximum height of the assessed profile $\mathrm{Rz}$ (pinion, TiAIN+DLC, MADIT PP 90H)

\begin{tabular}{c|c|c|c|c|c|c|c|c}
\hline \multirow{2}{*}{$\begin{array}{c}\text { Load } \\
\text { level }\end{array}$} & \multicolumn{4}{|c|}{ Tip diameter } & \multicolumn{4}{c}{ Reference diameter } \\
\cline { 2 - 8 } & $n$ & $\overline{\mathrm{Rz}}(\mu \mathrm{m})$ & $S(\mu \mathrm{m})$ & $S_{\overline{\mathrm{Rz}}}(\mu \mathrm{m})$ & $n$ & $\overline{\mathrm{Rz}}(\mu \mathrm{m})$ & $S(\mu \mathrm{m})$ & $S_{\overline{\mathrm{Rz}}}(\mu \mathrm{m})$ \\
\hline 3 & 10 & 4.770 & 0.072 & 0.023 & 10 & 3.680 & 0.081 & 0.026 \\
\hline 4 & 10 & 5.260 & 0.061 & 0.019 & 10 & 3.270 & 0.058 & 0.018 \\
\hline 5 & 10 & 4.830 & 0.071 & 0.023 & 10 & 3.410 & 0.082 & 0.026 \\
\hline 6 & 10 & 5.770 & 0.073 & 0.023 & 10 & 3.420 & 0.063 & 0.020 \\
\hline 7 & 10 & 5.570 & 0.069 & 0.022 & 10 & 3.590 & 0.062 & 0.019 \\
\hline 7.5 & 10 & 5.480 & 0.077 & 0.024 & 10 & 2.960 & 0.085 & 0.027 \\
\hline 8 & 10 & 3.540 & 0.059 & 0.019 & 10 & 2.550 & 0.098 & 0.031 \\
\hline 9 & 10 & 5.010 & 0.063 & 0.020 & 10 & 3.110 & 0.083 & 0.026 \\
\hline 10 & 10 & 5.260 & 0.090 & 0.029 & 10 & 3.630 & 0.087 & 0.028 \\
\hline 11 & 10 & 4.990 & 0.069 & 0.022 & 10 & 3.890 & 0.110 & 0.035 \\
\hline 12 & 10 & 4.310 & 0.064 & 0.020 & 10 & 4.470 & 0.085 & 0.027 \\
\hline
\end{tabular}

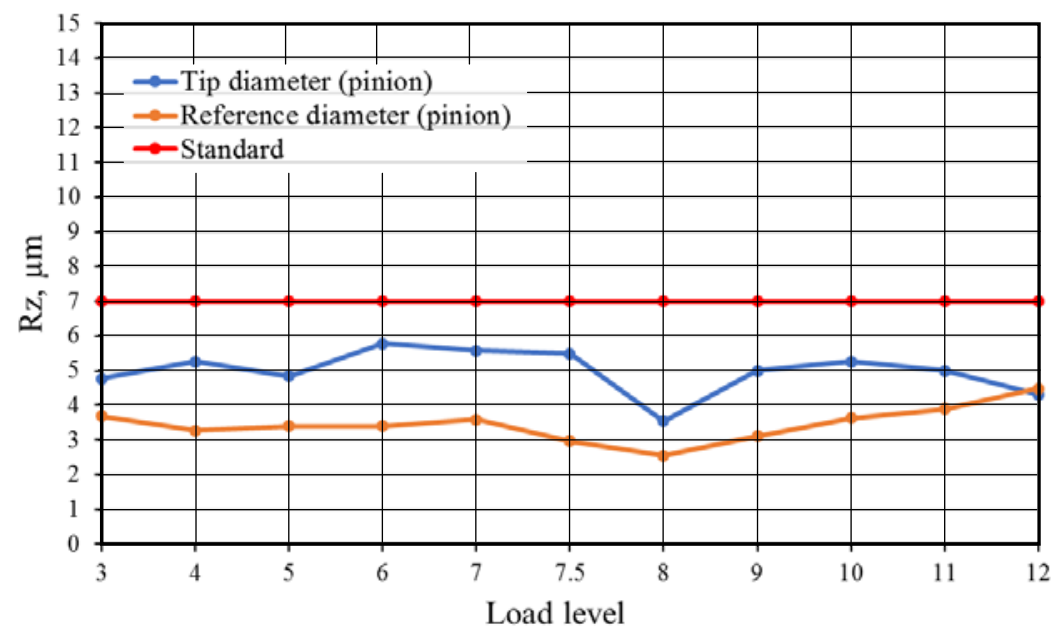

Fig. 7. Dependence of change maximum height of the assessed profile $R z$ on load level for TiAlN+DLC in MADIT PP 90H (pinion) 
Values of the maximum height of the assessed profile Rz (gear, TiAlN+DLC, MADIT PP 90H)

\begin{tabular}{c|c|c|c|c|c|c|c|c}
\hline \multirow{2}{*}{$\begin{array}{c}\text { Load } \\
\text { level }\end{array}$} & \multicolumn{5}{|c|}{ Tip diameter } & \multicolumn{4}{c}{ Reference diameter } \\
\cline { 2 - 9 } & $n$ & $\overline{\mathrm{Rz}}(\mu \mathrm{m})$ & $S(\mu \mathrm{m})$ & $S_{\overline{\mathrm{Rz}}}(\mu \mathrm{m})$ & $n$ & $\overline{\mathrm{Rz}}(\mu \mathrm{m})$ & $\mathrm{S}(\mu \mathrm{m})$ & $S_{\overline{\mathrm{Rz}}}(\mu \mathrm{m})$ \\
\hline 3 & 10 & 5.530 & 0.086 & 0.027 & 10 & 5.680 & 0.078 & 0.025 \\
\hline 4 & 10 & 6.560 & 0.089 & 0.028 & 10 & 5.210 & 0.074 & 0.023 \\
\hline 5 & 10 & 4.750 & 0.105 & 0.033 & 10 & 5.910 & 0.091 & 0.029 \\
\hline 6 & 10 & 3.810 & 0.090 & 0.028 & 10 & 4.360 & 0.086 & 0.027 \\
\hline 7 & 10 & 5.870 & 0.074 & 0.024 & 10 & 6.050 & 0.096 & 0.030 \\
\hline 7.5 & 10 & 6.440 & 0.104 & 0.033 & 10 & 3.410 & 0.077 & 0.024 \\
\hline 8 & 10 & 4.780 & 0.107 & 0.034 & 10 & 5.470 & 0.091 & 0.029 \\
\hline 9 & 10 & 5.720 & 0.0106 & 0.033 & 10 & 4.580 & 0.088 & 0.028 \\
\hline 10 & 10 & 6.610 & 0.117 & 0.037 & 10 & 2.930 & 0.087 & 0.027 \\
\hline 11 & 10 & 4.480 & 0.085 & 0.027 & 10 & 3.290 & 0.112 & 0.036 \\
\hline 12 & 10 & 5.640 & 0.117 & 0.037 & 10 & 2.990 & 0.104 & 0.033 \\
\hline
\end{tabular}

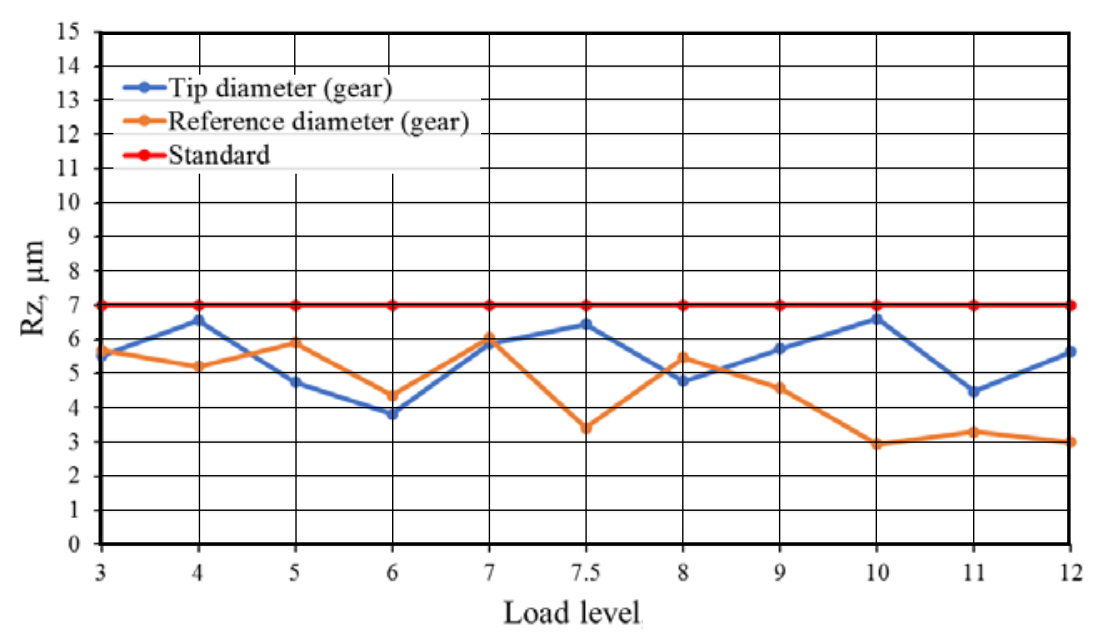

Fig. 8. Dependence of change maximum height of the assessed profile $\mathrm{Rz}$ on load level for TiAIN+DLC in MADITPP $90 H$ (gear)

It is clear from the results that values of the maximum height of the assessed profile $\mathrm{Rz}$ did not exceed $7 \mu \mathrm{m}$ established by the standard.

Compared with previous research at the Centre of Innovations SUT in Bratislava, we can conclude that the adhesive properties and the wear resistance of the coatings nACRo4 and TiALN+DLC are better than in previous researches done on TiCN-MP coating + MOVIC [16], where occurred scuffing at 11th load level and DLC coating [17], where scuffing occurred at 7th load level.

\section{Conclusion}

The experimental work was carried out on HCR gears coated by PVD coatingTiAlN+DLC. As lubrication environments were selected conventional oil MADIT PP90H and biological oil OMW BiogearS150. Coating was deposited in ACR PVD mode with the $\pi 411$ PLUS device. The coating was produced at a thickness of $7 \mu \mathrm{m}$ and tested according to STN 656280 standard. The measured values were evaluated statistically in the tables and graphically as the dependency of the maximum height of the assessed profile $\mathrm{Rz}$ in relation to the load level. From obtained values, it is evident that the maximum height of the assessed profile Rz did not exceed interval $7 \mu \mathrm{m}$ established by the standard. Thus, we can conclude that scuffing did not occur, and the adhesive properties and the wear resistance of selected coating is satisfactory for both lubricating mediums. 
Acknowledgments

Contribution has been prepared within the solving of scientific grant project VEGA 1/0227/15 "Study of tribological characteristics of the new high hard coatings on materials suitable for gearings". Nomenclature Symbols

$\varepsilon_{\alpha}$ - transverse contact ratio;

$h_{a}{ }^{*}$ - addendum;

$h_{f}^{*}$ - dedendum;

$\mathrm{Rz}$ - maximum height of the assessed profile, $\mu \mathrm{m}$;

$\alpha$ - reference pressure angle, ${ }^{\circ}$;

$\beta$ - reference cylinder helix angle, ${ }^{\circ}$;

$i$ - transmission ratio;

$a$ - center distance, $\mathrm{mm}$;

$m$ - module, $\mathrm{mm}$;

$x$ - profile shift correction;

$d_{a}$ - tip diameter, mm;

$b$ - facewidth, mm;

$z$ - number of teeth;

$\overline{\mathrm{Rz}}$ - arithmetic mean of the maximum height of the assessed profile $\mathrm{Rz}, \mu \mathrm{m}$;

$S$ - standard deviation of the maximum height of the assessed profile $\mathrm{Rz}, \mu \mathrm{m}$;

$S_{\overline{\mathrm{Rz}}}$ - standard error of mean of the maximum height of the assessed profile Rz, $\mu \mathrm{m}$.

\section{Література}

1. Test methods for gear lubricants / B.R. Hoehn, et.al. Gorivaimaziva. 2008. Vol. 47, No. 2, P. 129-157.

2. Castro J., Seabra J. Influence of mass temperature on gear scuffing. Tribology International. 2018 . Vol. 119, P. 27-37.

3. New scuffing test methods for the determination of the scufing resistance of coated gears / R. Michalczewski, et al. Tribology - Fundamentals and advancements. 2013. Vol. 12, No. 4. P.187-215.

4. Kučera M., Rusnák J. Study of tribological properties of surface applied materials by selected welding technologies: methods, instruments and interpretation. SUA in Nitra, 2008. Nitra.

5. Savolainen M., Lehtovaara A. An experimental investigation of scuffing initiation due to axial displacement in a rolling/sliding contact. Tribology International. 2018. Vol. 119. P. 688-697.

6. Bošanský M., Vanya A., Vereš M. (2013) Evaluation of properties of selected coatings on steel C60E in terms of their use in gearing. Advanced Materials Research. 2013. No. 25. P. 81-85.

7. Kadnár M., Rusnák J., Tkáč Z., Bošanský M. Tribological experiments in automobile industry. Visnik nacional'novo techničnovo universitetu "CHPI" 2017. Tribological experiments in automobile industry. Visnik nacional'novo techničnovo universitetu "CHPI” 2017.

8. Li S., Anisetti A. On the flash temperatureofgearcontactsunderthe tribo-dynamic condition. In: Tribology International. 2016. Vol 97, P. 6-13. ISSN0 301-679x.

9. Optimalization of HCR gearing geometry using generalized particle swarm optimalization algorithm / M. Vereš, et. al. Modern methods of construction design. 2014. Vol. 109, No. 10. P. 539-545.

10. Bošanský M., Rusnák J. Assessment of options for applications TICN-MP + movic deposited on the convex-concave gearing working in interaction with the ecological lubricant. Proceedings of 58th international conference of Machine Design Departments. ICMD 2017: Praha, 6 - 8. 9. 2017. 1. vyd. Praha: Czech University of Life Sciences Prague, 2017, pp. 44-49.

11. STN 656280:1985. Lubricants. Mechanical testing of lubricants in the FZG gear ring test machine. Slovak Standard Institute. 1985.

12. A New Generation of PVD Coatings for High-Performance Gear Hobbing /A. Lümkemann, et al. Preprint from A Coatings Conference, Thessaloniki, Greece, Oct.1 - 3, 2014, Platit.

13. Evaluation of Properties of Selected Coatings on Aisi Grade 18Ni(250) Maraging Steel in Terms oftheiruse in Gears / M. Bošanský, et al. Advanced Materials Research. 2013. Vol. 746. P. 179-185.

14. Nanostructure reactive plasma sprayed TiCN coating / M. Pengbo, et al. Surface and Coatings Technology. 2017. Vol. 309. P. 1-5.

15. Ingram M., Hamer C., Spikes H. A new scuffing test using contra-rotation. Wear. 2015. Vol. 328-329. P. 229-240. ISSN 0043-1648. 
16. Mišány J. Influence of the building machine transmission and the possibility to increase its carrying capacity with a focus to reduce the environmental load of soil - Dissertation thesis. SUT in Bratislava, Bratislava. 2015.

17. Zápotočný J. Analysis of qualitative and quantitative characteristics of placed films in the system 'film - cog side’ from the tribological point of view - Dissertation thesis. SUT in Bratislava, Bratislava. 2014.

\section{References}

1. Hoehn, B.R., et.al. (2008). Test methods for gear lubricants. Gorivaimaziva, 47, 2, 129-157. HOEHN, B.R., et.al. (2008). Test methods for gear lubricants. Gorivaimaziva, 47, 2, 129-157.

2. Castro, J., Seabra, J. (2018). Influence of mass temperature on gear scuffing. Tribology International, 119, 27-37, ISSN: 0301-679x.

3. Michalczewski, R., et al. (2013). New scuffing test methods for the determination of the scufing resistance of coated gears. Tribology - Fundamentals and advancements, 12, 4, 187-215.

4. Kučera, M., \& Rusnák, J. (2008). Study of tribological properties of surface applied materials by selected welding technologies: methods, instruments and interpretation. SUA in Nitra, Nitra.

5. Savolainen, M., \& Lehtovaara, A., (2018). An experimental investigation of scuffing initiation due to axial displacement in a rolling/sliding contact. Tribology International, 119, pp. 688-697, ISSN 0301679x.

6. Bošanský, M., Vanya, A., \& Vereš, M. (2013). Evaluation of properties of selected coatings on steel C60E in terms of their use in gearing. Advanced Materials Research, 25, 81-85.

7. Kadnár, M., Rusnák, J., Tkáč, Z., \& Bošanský, M., (2017). Tribological experiments in automobile industry. Visnik nacional'novo techničnovo universitetu "CHPI".

8. Li, S., \& Anisetti, A. (2016). On the flash temperatureofgearcontactsunderthe tribo-dynamic condition. Tribology International, 97, 6-13, ISSN0 301-679x.

9. Vereš, M., et. al. (2014). Optimalization of HCR gearing geometry using generalized particle swarm optimalization algorithm. Modern methods of construction design, 109, No. 10, 539-545.

10. Bošanský, M., \& Rusnák, J., (2017). Assessment of options for applications TICN-MP + movic deposited on the convex-concave gearing working in interaction with the ecological lubricant. Proceedings of 58th international conference of Machine Design Departments. ICMD 2017: Praha, 6-8. 9. 2017. 1. vyd. Praha: Czech University of Life Sciences Prague, 2017, pp. 44-49.

11. STN 656280:1985. (1985). Lubricants. Mechanical testing of lubricants in the FZG gear ring test machine. Slovak Standard Institute.

12. Lümkemann, A., et al. (2014). A New Generation of PVD Coatings for High-Performance Gear Hobbing. Preprint from A Coatings Conference, Thessaloniki, Greece, Oct.1-3, 2014, Platit.

13. Bošanský, M., et al. (2013). Evaluation of Properties of Selected Coatings on Aisi Grade 18Ni(250) Maraging Steel in Terms oftheiruse in Gears. Advanced Materials Research, 746 (2013), 179-185.

14. Pengbo, M., et al. (2017). Nanostructure reactive plasma sprayed TiCN coating. Surface and Coatings Technology, 309, 1-5.

15. Ingram, M., Hamer, C., Spikes, H. (2015). A new scuffing test using contra-rotation. Wear, 328-329, 229-240, ISSN 0043-1648.

16. Mišány, J. (2015). Influence of the building machine transmission and the possibility to increase its carrying capacity with a focus to reduce the environmental load of soil. Dissertation thesis. SUT in Bratislava, Bratislava.

17. Zápotočný, J. (2014). Analysis of qualitative and quantitative characteristics of placed films in the system 'film - cog side' from the tribological point of view. Dissertation thesis. SUT in Bratislava, Bratislava.

Фурстензеллер Адам; Adam Fürstenzeller, e-mail: xfurstenzell@is.uniag.sk

Тот Франтішек; František Tóth, e-mail: frantisek.toth@uniag.sk

Каднар Мілан; Milan Kadnár, e-mail:milan.kadnar@uniag.sk

Руснак Юрий; Juraj Rusnák, e-mail: juraj.rusnak@uniag.sk

Бошански Мірослав; Miroslav Bošanský, e-mail: miroslav.bosansky@stuba.sk

Мраз Мірослав; Miroslav Mráz, e-mail: xmrazm@is.uniag.sk 